\title{
Effect of supplementation of branched chain amino acids in muscle damage induced by resistance training
}

\author{
Antonio Felipe Correa Marangon*, Vinícius Vieira Lacerda, Ronald Lamas Corrêa \\ From International Society of Sports Nutrition: 7th Annual ISSN Conference and Expo \\ Clearwater Beach, FL, USA. 24-26 June 2010
}

\section{Background}

Analyze the effect of supplementation of branched-chain amino acid in muscle damage after resistence training measured by serum creatinine.

\section{Methods}

9 male individuals, aged between 20 and 35 years, weight lifters for at least 1 year, with a minimum of 4 times weekly frequency without nutritional counseling by a dietician, without the use of dietary supplements, medications or any condition diagnosed whatsoever. They exercised in the barbell bench press, leg press $45^{\circ}$ and Extension Ankle (donkey) exercises, in that order. It was performed 3 sets of each exercise, with 2 minutes between sets and 30 seconds between exercises, charged to $85 \%$ of 1 RM and 6 repetitions in each series. 30 minutes before the execution of the exercises, the participants consumed $5 \mathrm{~g}$ of ACR (2.5g of leucine, isoleucine $1.25 \mathrm{~g}$ and $1.25 \mathrm{~g}$ valine), or empty capsules (placebo). Blood samples were taken 30 minutes before $(\mathrm{C} 1)$, immediately after $(\mathrm{C} 2)$ and 30 minutes after training (C3) with a punction of the median basilic vein.

\section{Results}

Statistical analysis was performed using ANOVA and tstudent and significant difference was found between the ACR and Placebo groups ( $\mathrm{p}<0.05)$. On the consumption of ACR, values of serum creatinine were $0.2 \pm \mathrm{C} 11.17$, C2 $1.24 \pm 0.19$ and C3 $1.18 \mathrm{mg} / \mathrm{dL} \pm 0.21$ and Placebo $1.39 \pm 0.31,1.57 \pm 0.48,1.5 \mathrm{mg} / \mathrm{dL} \pm 0.25$. With the administration of ACR, serum creatinine decreased by

Centro Universitário UniCEUB - Brazil
$27 \%$ in water samples which were collected immediately afterwards, and performed 30 minutes after exercise.

\section{Conclusions}

It may well be attributed to the BCAA the role of providing energy to skeletal muscle or decreasing muscle catabolism in resistance exercise.

Published: 15 September 2010

doi:10.1186/1550-2783-7-S1-P3

Cite this article as: Marangon et al:: Effect of supplementation of branched chain amino acids in muscle damage induced by resistance training. Journal of the International Society of Sports Nutrition 2010 7(Suppl 1):P3.
Submit your next manuscript to BioMed Central and take full advantage of:

- Convenient online submission

- Thorough peer review

- No space constraints or color figure charges

- Immediate publication on acceptance

- Inclusion in PubMed, CAS, Scopus and Google Scholar

- Research which is freely available for redistribution

Submit your manuscript at www.biomedcentral.com/submit
Biomed Central 